\title{
Relapsing hepatitis A infection with immunological sequelae
}

\author{
Deborah J. COOK, MD, FRCPC, ROBERT H. Riddell, MD, FRCPATH, FRCPC, MAx A. Chernesky, PHD, \\ Bruno J. Salena, MD, FRCPC, Renata SLAPSYS, PHD
}

\begin{abstract}
The clinical course of hepatitis A infection is usually benign. A patient with persistent anti-hepatitis A virus (HAV) IgM following icteric hepatitis A, vasculitis, arthritis and peripheral neuropathy is reported. The clinical, biochemical and serological features of relapsing hepatitis A are described. Can J Gastroenterol 1989;3(4):145-148

Key Words: Chronic active hepatitis, Hepatitis A virus, Relapsing hepatitis A

\section{Hépatite virale $\mathrm{A}$ récurrente et séquelles immunologiques}

RESUME: L'évolution clinique d'une hépatite virale A est habituellement bénigne. On rapporte le cas d'un patient chez qui l'on continue à détecter des $\operatorname{lgM}$ anti-HAV après une hépatite $\mathrm{A}$ ictérique, une vascularite, une arthrite et une neuropathie périphérique. Les caracteristiques cliniques, biochimiques et sérologiques de l'hépatite $\mathrm{A}$ récurrente sont décrites.
\end{abstract}

\section{I}

INFECTION WITH HEPATITIS A VIRUS (HAV), unlike hepatitis B, is uncommonly associated with extrahepatic manifestations (1). The duration of infection with HAV is variable but brief; liver function tests are usually normal within two months and chronicity has not been proven $(2-4)$. However, relapsing $\mathrm{HAV}$ infection has been linked to persistent HAV IgM antibody (anti-HAV IgM) (5-8).

A patient with relapsing hepatitis $\mathrm{A}$ infection, polyarthritis, vasculitis and peripheral neuropathy, who had persistent anti-HAV IgM for nine months is described.
Departments of Gastroenterology and Pathology, McMaster University Medical Centre; and SiJoseph's Hospital, Hamilton, Ontario

Correspondence: Dr D.J. Cook, Room IB7., McMaster University Medical Centre, 1200

Main Street West, Hamilton, Ontario L8N 325. Telephone (416) 521-2100

Received for publication March 1989. Accepted May 25, 1989

\section{CASE PRESENTATION}

A 57-year-old Caucasian female developed jaundice while in Zaïre in November 1987. Acute HAV infection was confirmed by positive HAV IgM. When asymptomatic two months later, the total bilirubin was 32 umol/L (normal less than 21); aspartate aminotransferase $54 \mathrm{iu} / \mathrm{L}$ (normal less than 35); alanine aminotransferase 80 $\mathrm{iu} / \mathrm{L}$ (normal less than 35); and alkaline phosphatase $195 \mathrm{iu} / \mathrm{L}$ (normal 30 to 120). Four months later, the patient was admitted to hospital with a one week history of left ankle arthritis and lower extremity skin rash.

Past medical history included a blood transfusion in 1983 for anemia of unknown etiology. There was no previous drug or alcohol use.

Physical examination was normal except for a left ankle effusion and purpuric, raised erythematous lesions over the lower extremities (Figure 1). Proprioception, vibration and pinprick sensation were impaired in a stocking distribution and ankle reflexes were absent. 


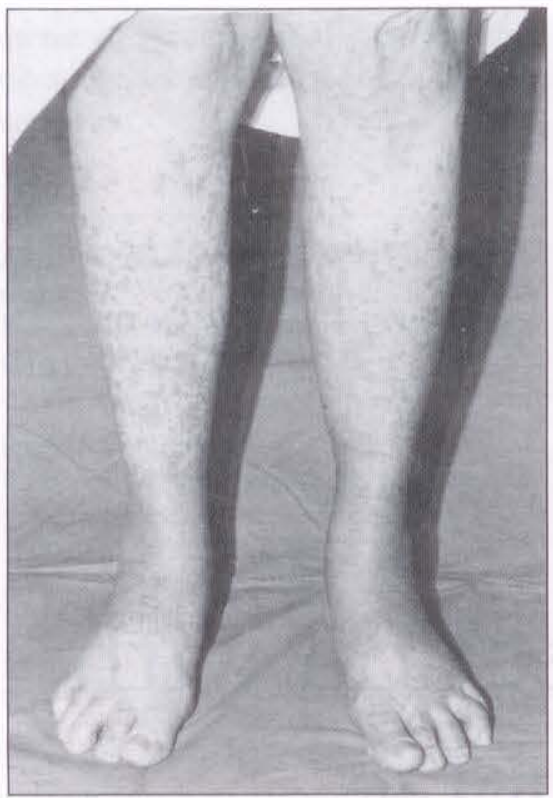

Figure 1) Confluent purpuric erythematous lesions over both lower extremities

Laboratory investigations included hemoglobin of $109 \mathrm{~g} / \mathrm{L}$ with a mean corpuscular volume of $90.6 \mathrm{fL}$. The platelets, white blood cell count and differential, electrolytes, urea and creatinine were normal. Aspartate aminotransferase was $333 \mathrm{iu} / \mathrm{L}$; alanine aminotransferase $275 \mathrm{iu} / \mathrm{L}$; gamma glutamyl transferase $268 \mathrm{iu} / \mathrm{L}$; alkaline phosphatase $386 \mathrm{iu} / \mathrm{L}$; and bilirubin 15 umol/L. Serum iron, ferritin, vitamin B12, red cell folate, copper and comple-

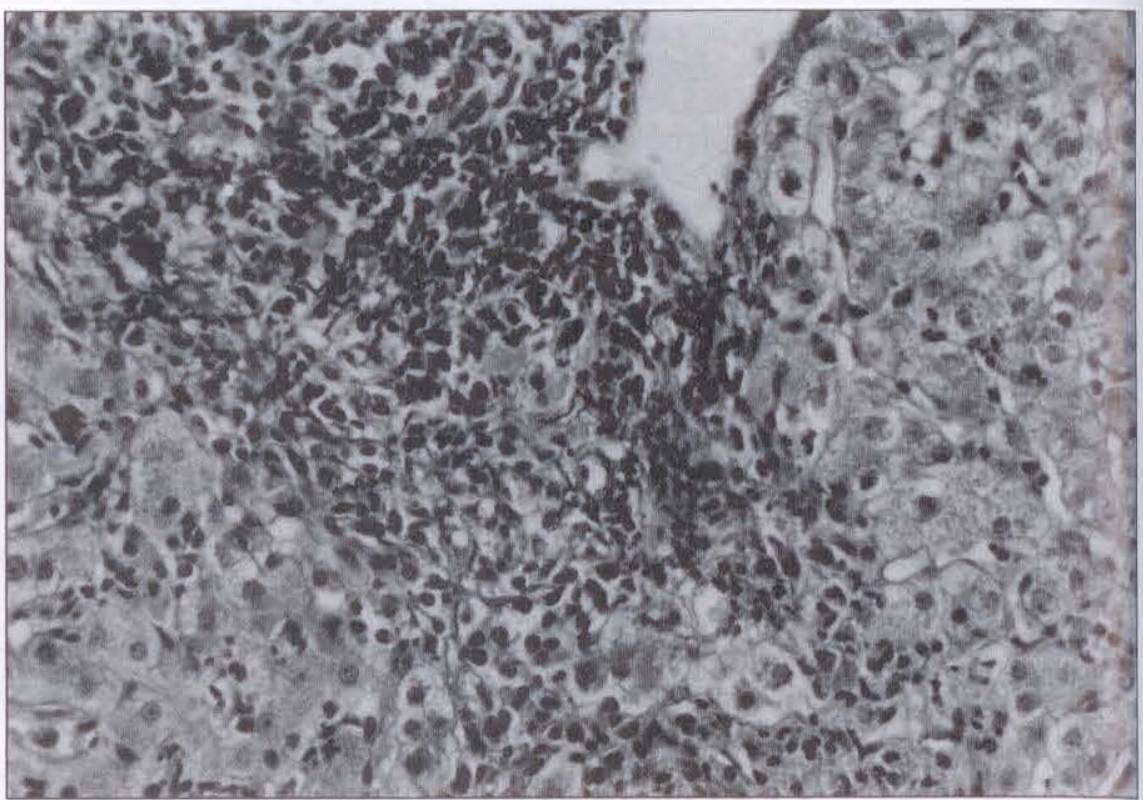

Figure 3) The liver biopsy performed four months after the onset of jaundice shows infiltration of a portal tract by mononuclear cells with piecemeal necrosis and foci of infiltration by chronic inflam. matory cells within the lobules. Hematoxylin and eosin $\times 145$

ment levels were normal. Rheumatoid factor was positive at $2060 \mathrm{iu} / \mathrm{mL}$ but antinuclear antibody, antimitochondrial antibody, antismooth muscle antibody and cryoglobulins were negative. Serum $\operatorname{IgA}$ was $3.46 \mathrm{~g} / \mathrm{L}$ (normal 0.17 to 3.45 ), $\operatorname{IgG} 33.3 \mathrm{~g} / \mathrm{L}$ (normal 6.5 to 15.0 ) and IgM 2.87 (normal 0.42 to 2.1). Hepatitis $B$ surface antigen and antibodies to hepatitis B surface antigen, hepatitis $\mathrm{B}$ core antigen, human immunodeficiency virus, cytomegalo-

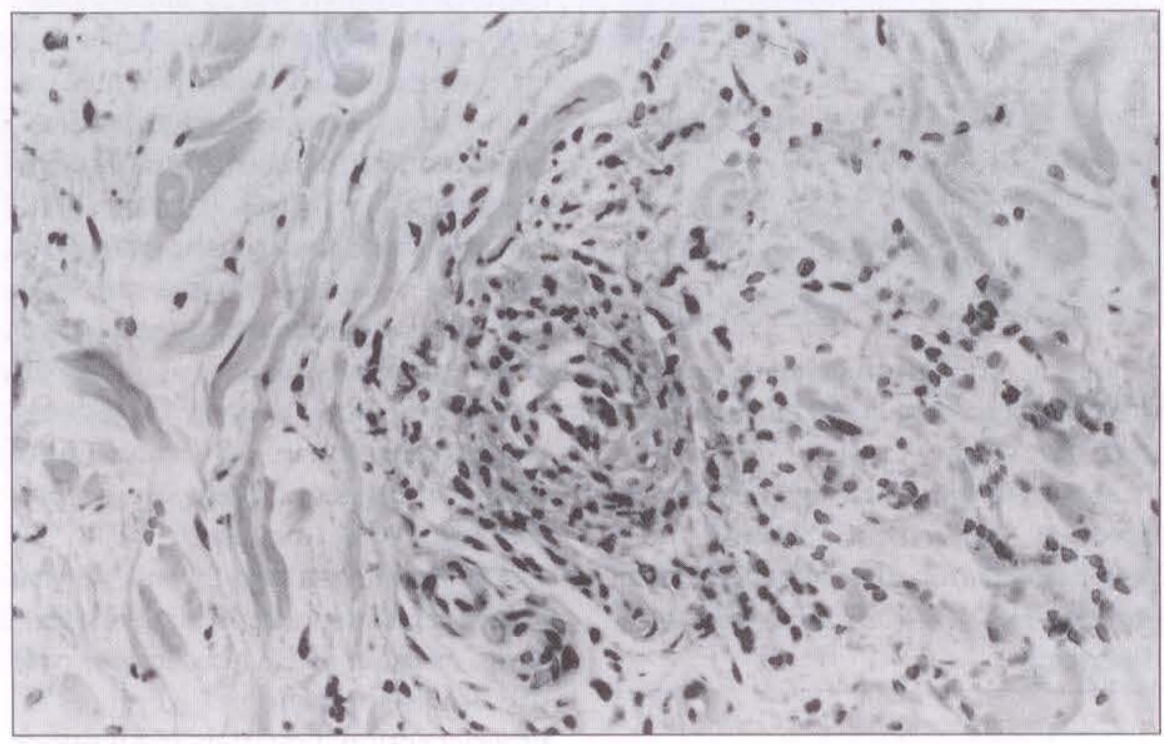

Figure 2) Skin biopsy showing leukocytoclastic vasculitis. The thickened vessel wall is infiltrated by neutrophil polymorphs, some of which are fragmented. Perivascular extravasation of erythrocytes is noted. Hematoxylin and eosin $\times 140$ virus and Epstein Barr virus were nega: tive. The anti-HAV IgM radioimmunoassay was positive (Abbott Laboratories, Chicago, Illinois).

Skin biopsy revealed an intact epidermis; several small dermal arteries showed the features of a leukocytoclas. tic vasculitis with endothelial swelling infiltrated by neutrophils. Extravasa. tion of erythrocytes in the perivascular connective tissue was noted (Figure 2).

An abdominal ultrasound and liver spleen scan were unremarkable. A liver biopsy revealed normal architecture, although the portal tracts were expanded by a chronic inflammatory infiltrate including lymphocytes, plasma cells and histiocytes. There was inflammation across the limiting plate with isolation of hepatocytes (Figure 3). The lobules also contained a focal infiltrate of similar inflammatory cells and acidophil bodies were identified (Figure 4). There was no pericentral loss of hepatocytes or cholestasis. Minimal iron was present and the diastase-PAS stain showed no evidence of alpha! antitrypsin deficiency. Sections of liver and epidermis stained for hepatitis A antigen with fluorescent reagent were negative.

One week after hospital admission, a right wrist and left knee effusion developed. The aspartate amino. 


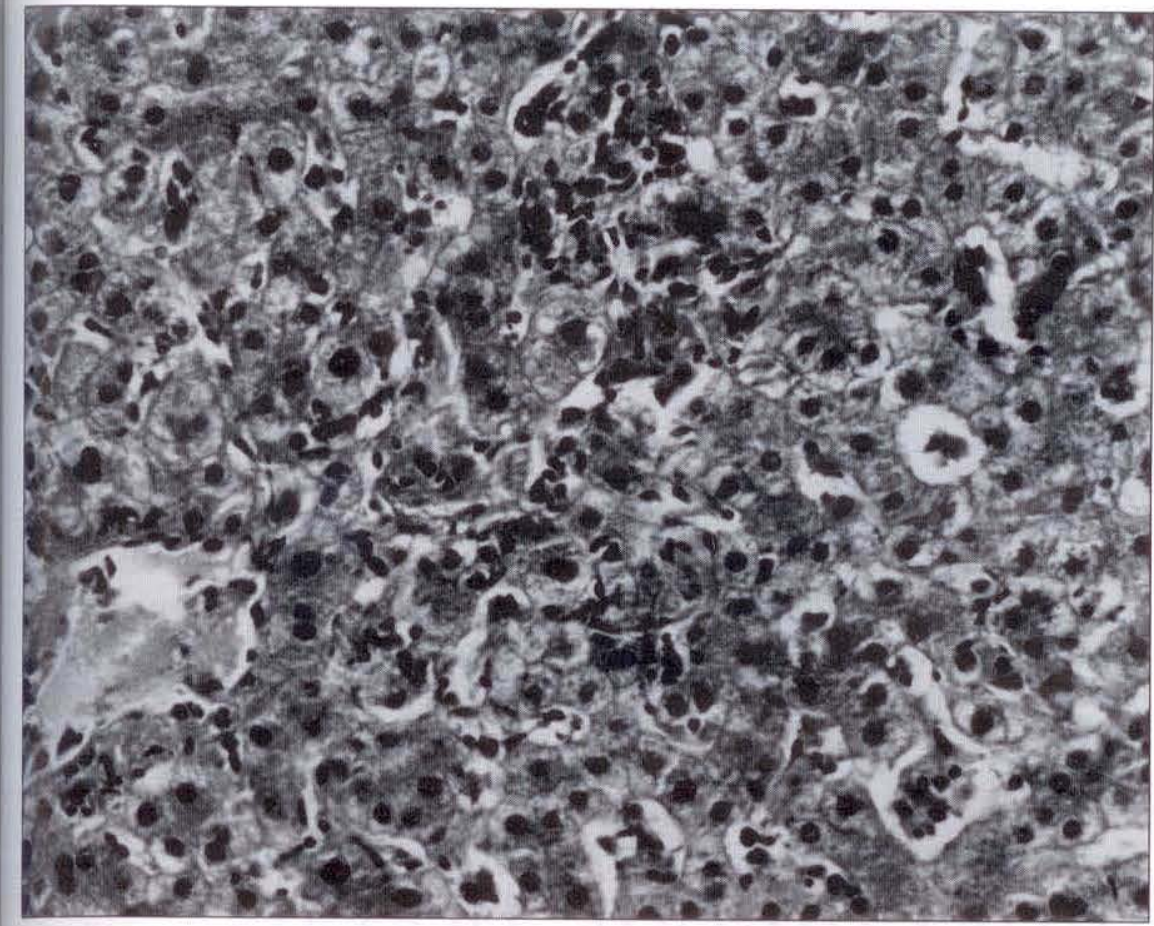

Figure 4) Pericentral region showing lobular inflammation with chronic inflammmatory cells between hepatocytes and in the sinusoids but with no loss of hepatocytes around the central vein. Occasional acidophil bodies are present. Hematoxylin and eosin $\times 955$

transferase and alanine aminotransferase increased to greater than $500 \mathrm{iu} / \mathrm{L}$. Prednisone $30 \mathrm{mg}$ daily was prescribed, symptoms improved and the transaminases began to decrease.

Six weeks later, the patient presented with epigastric pain and a hemoglobin of $73 \mathrm{~g} / \mathrm{L}$. Examination revealed a resolving lower extremity rash. No red cell fragments or cryoglobulins were noted; haptoglobin binding was greater than $0.3 \mathrm{~g} / \mathrm{L}$ and Coomb's test was negative. Endoscopy revealed a large duodenal ulcer. Serum concentrations were: alanine aminotransferase $59 \mathrm{iu} / \mathrm{L}$, aspartate aminotransferase $48 \mathrm{iu} / \mathrm{L}$, gamma glutamyl transferase $166 \mathrm{iu} / \mathrm{L}$ and alkaline phosphatase $177 \mathrm{iu} / \mathrm{L}$. The repeat anti-HAV $\operatorname{IgM}$ was positive. Prednisone was discontinued, two units of blood were transfused and ranitidine was prescribed. The patient recovered fully and liver function tests returned to normal.

The anti-HAV IgM persisted until July 1988, providing reactions above 2000 counts/min (positive cut-off 660 counts/min).

Repeated treatment of sera with rheumatoid factor absorbent (Gull Laboratories, Salt Lake City, Utah) failed to reduce the positive counts in the anti-HAV lgM radioimmunoassay. In August 1988, nine months after the onset of jaundice, the anti-HAV IgG became positive while the anti-HAV
Figure 5) Clinical course of liver disease
$\operatorname{Ig} M$ became negative and the rheumatoid factor disappeared. Liver function tests in January 1989 were all within normal limits (Figure 5). The patient continued to feel well and returned to Africa.

\section{DISCUSSION}

Acute viral hepatitis A usually has a brief clinical course. Less than 10\% of patients reportedly have elevated transaminases after 14 weeks and anti-HAV IgM usually disappears by 120 days (6). However, in one series, five of 37 patients had persistence of this marker for 200 days and anti-HAV IgM has been documented 14 months after HAV infection $(1,6)$. Persistent antiHAV IgM may also accompany relapsing hepatitis A (4).

The transaminases in the present patient remained elevated eight months after jaundice developed and increased dramatically with the onset of arthritis and vasculitis. The detection of anti-HAV IgM for nine months strongly suggests that relapsing HAV was responsible. To exclude the possibility of a false positive anti-HAV IgM test due to rheumatoid factor, preab. sorption of the sera with antirheumatoid factor was performed, which did not reduce the counts, confirming persistence of this marker.

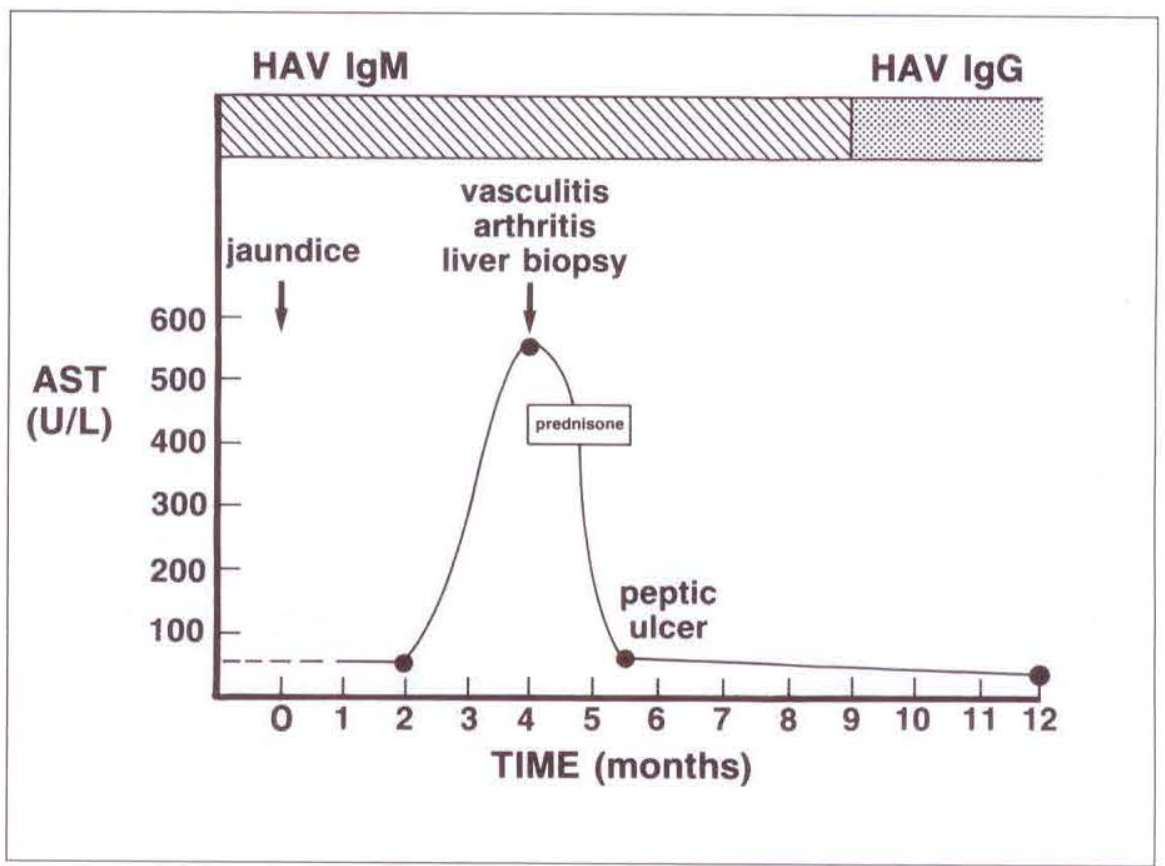


Relapsing HAV is often heralded by an increase in transaminases, although original attacks of hepatitis may be duplicated in a milder form (8). It has been postulated that the virus may not be eliminated during the first hepatitis episode, thus producing a second infection or inducing an autoimmune response (7). However, relapsing hepatitis appears to be more common following exposure to more than one hepatitis virus, suggesting two distinct infections rather than relapse of an original infection (8). Although hepatitis B, cytomegalovirus, Epstein Barr virus and human immunodeficiency virus serology were negative in this case, antecedent post transfusion non- $A$ non- $B$ hepatitis, frequently associated with multiphasic aminotransferase patterns, cannot be absolutely excluded (8).

Hepatitis B was excluded serologically. Autoimmune or lupoid hepatitis is possible in this patient; a polyclonal gammopathy is common and the antinuclear antibody and antismooth muscle antibody may be negative in up to $50 \%$ of cases (2). This patient had not abused alcohol or ingested oxyphenacetin, methyldopa, isoniazid,

ACKNOWLEDGEMENTS: The authors thank Drs H. Rashogi and R. Adachi, Department of Medicine, and Dr J.M. Kay, Department of Pathology, St Joseph's Hospital, Hamilton, Ontario for his help with this case.

\section{REFERENCES}

1. Wright R, Millward-Sadler GH, Bull FG. Acute viral hepatitis. In: Wright R, Millward-Sadler GH, Alberti KGMM, et al, eds. Liver and Biliary Disease, 2nd edn. London: WB Saunders, 1985:677767.

2. Wright R, Millward-Sadler GH. Chronic hepatitis. In: Wright R, Millward-Sadler GH, Alberti KGMM, et al, eds. Liver and Biliary Disease, 2nd edn. London: WB Saunders, 1985:769-820. nitrofurantoin or other drugs associated with abnormal liver function tests or chronic hepatitis.

The progression of HAV infection to chronic liver disease has not been proven by retrospective or case control studies (2). Changes in liver morphology after hepatitis A usually last two to four weeks and almost always resolve without distortion of liver architecture (4). In a series of 25 patients with acute hepatitis A, two liver biopsies performed before six months had elapsed showed changes compatible with chronic active hepatitis (8); histologic features of chronic hepatitis have also been noted in patients afflicted by foodborne outbreaks of hepatitis A (9). However, alternate etiologies of chronic active hepatitis in these cases were not adequately evaluated and histologic follow-up was not widely available at six months. Because this patient had converted to HAV $\operatorname{IgG}$ and had normal liver function tests 10 months after the onset of jaundice, and remained in good health five months thereafter, a repeat liver biopsy was difficult to justify.

Relapsing hepatitis A appears to be uncommon, with two of 25 patients reported in one series (10) and two of 99 patients reported in another (11). The association of arthritis and leukocytoclastic vasculitis with hepatitis A in this patient is extremely rare. Only two other patients have been reported by Inman and co-workers (5) with relapsing HAV infection, arthritis and cryoglobulinemia, one of whom had cutaneous vasculitis. Although peripheral neuropathy has been documented during acute HAV infection, if has not previously been associated with relapsing HAV and was likely secondary to vasculitis in this case. Electro. myography was not performed. However, no other cause of self limited peripheral neuropathy was identified.

The persistence of anti-HAV $\lg \mathrm{M}$ for nine months, the unusual presence of vasculitis, arthritis, peripheral neuropathy and fluctuating amino. transferases in this patient, as well as the presence of an unresolved acute viral hepatitis four months after the initial presentation, are compatible with relapsing HAV infection. Although relapses of hepatitis $\mathrm{A}$ are of variable severity (8), conservative management appears to be justified by ultimate resolution of this condition.
3. Seeff LB. Diagnosis, therapy and prognosis of viral hepatitis. In: Zakim D, Boyer TD, eds. Hepatology: A Textbook of Liver Disease. Philadel. phia: WB Saunders, 1982:911-71.

4. Friedman LS, Dienstag JL. The disease and its pathogenesis. In: Gerety RJ, ed. Hepatitis A. Orlando: Academic Press, 1984:55-79.

5. Inman RD, Hodge M, Johnston MEA, Wright J, Heathcote J. Arthritis, vasculitis and cryoglobulinemia as. sociated with relapsing hepatitis A virus infection. Ann Intern Med 1986; 105:700-3.

6. Kao HW, Ashcavai M, Redeker AG. The persistence of hepatitis A IgM antibody after acute clinical hepatitis A. Hepatology 1984:4:933-6.

7. Gruer LD, McKendrick MW, Beeching NJ, Beddes AM. Relapsing hepatitis associated with hepatitis A virus. Lan. cet 1982;ii:163. (Letter)

8. Jacobson IM, Nath BJ, Dienstag JL. Relapsing viral hepatitis A. J Med Virol 1985;16:163-9.

9. Routenberg IA, Dienstag JL, Harrison WO, et al. Foodborne outbreak of hepatitis A: Clinical and laboratory features of acute and protracted illness. Am J Med Sci 1979;278:123-37.

10. Weir WR, Mellor JA, Smith H, Tyrell DA. Significance of hepatitis enzyme levels at discharge in acute viral hepatitis. J Infect 1981;3:309-15.

11. Bamber M, Thomas HC, Bannister B, Sherlock S. Acute type A, B, and non$A$, non- $B$ hepatitis in a hospital population in London: Clinical and epidemiological features. Gut $1983 ; 24: 561-4$ 


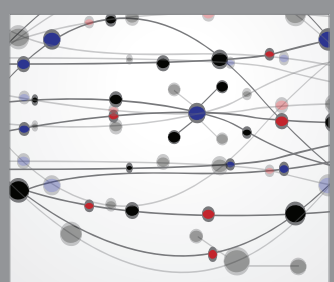

The Scientific World Journal
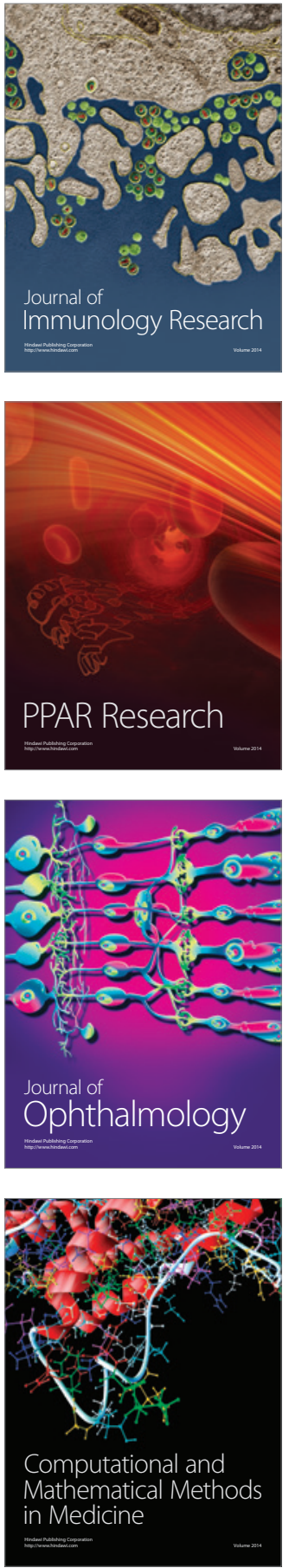

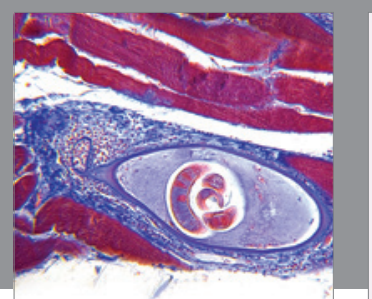

Gastroenterology Research and Practice

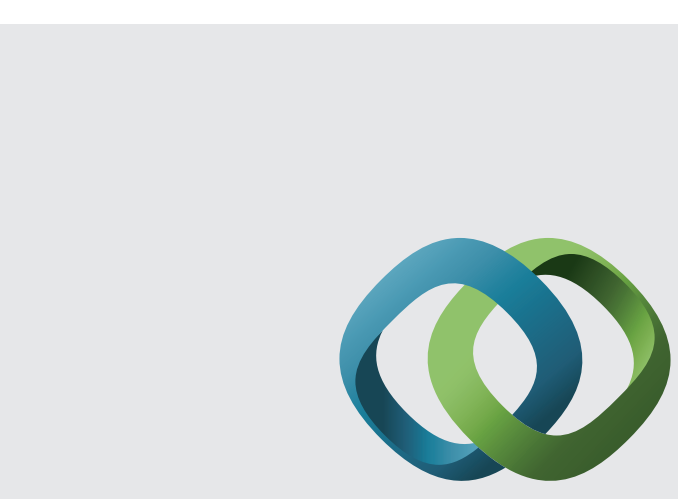

\section{Hindawi}

Submit your manuscripts at

http://www.hindawi.com
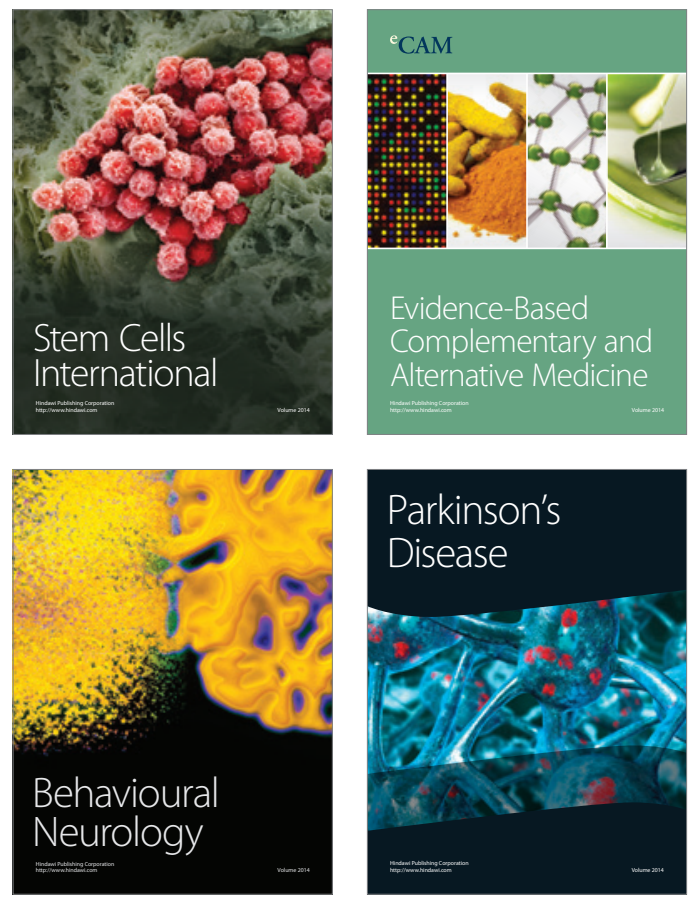
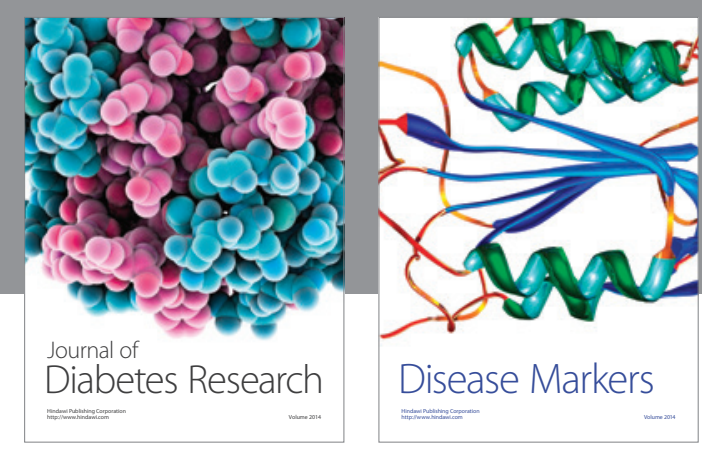

Disease Markers
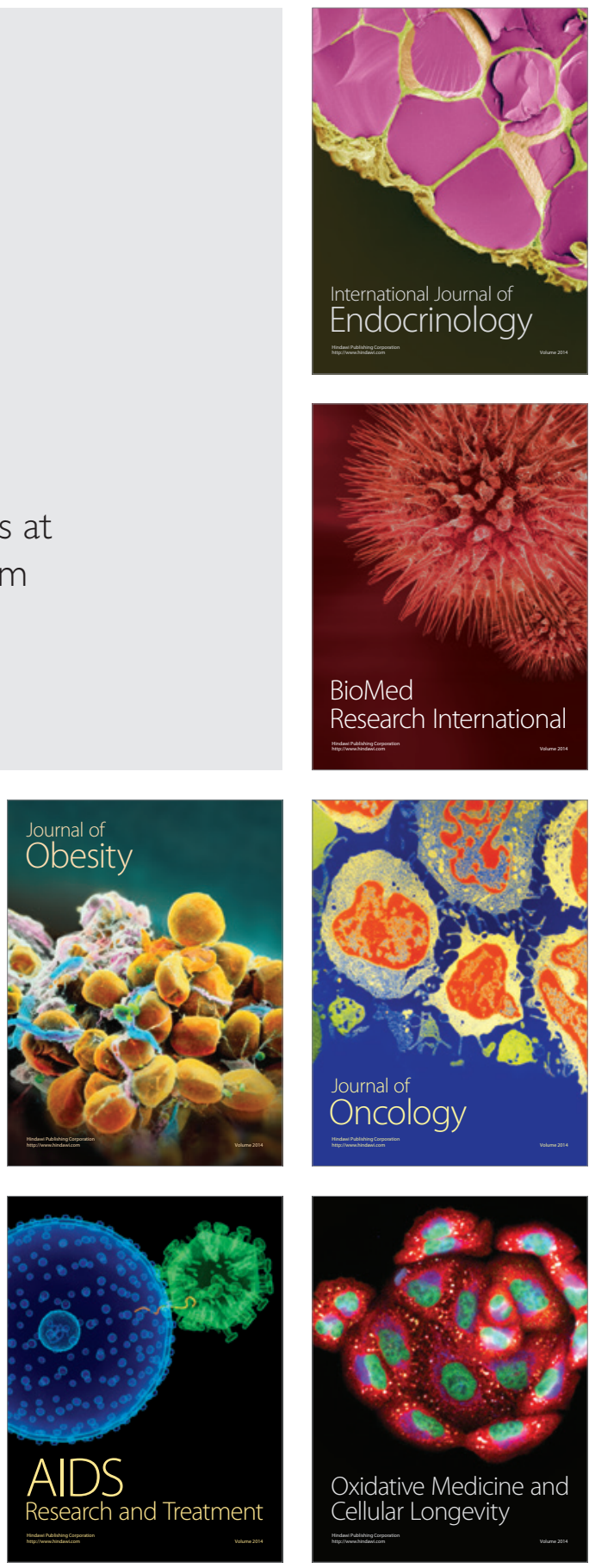